\title{
Genomic diversity and versatility of Lactobacillus plantarum, a natural metabolic engineer
}

\author{
Roland J Siezen ${ }^{1,2,3,4^{*}}$, Johan ET van Hylckama Vlieg ${ }^{1,3,5}$ \\ From 10th Symposium on Lactic Acid Bacterium \\ Egmond aan Zee, the Netherlands. 28 August - 1 September 2011
}

\begin{abstract}
In the past decade it has become clear that the lactic acid bacterium Lactobacillus plantarum occupies a diverse range of environmental niches and has an enormous diversity in phenotypic properties, metabolic capacity and industrial applications. In this review, we describe how genome sequencing, comparative genome hybridization and comparative genomics has provided insight into the underlying genomic diversity and versatility of $L$. plantarum. One of the main features appears to be genomic life-style islands consisting of numerous functional gene cassettes, in particular for carbohydrates utilization, which can be acquired, shuffled, substituted or deleted in response to niche requirements. In this sense, L. plantarum can be considered a "natural metabolic engineer".
\end{abstract}

\section{Background}

The lactobacilli constitute a major group of the Lactic Acid Bacteria (LAB). They occupy a wide range of niches and are generally found in environments with high levels of carbohydrates, such as food products (dairy products, fermented meat, sourdoughs) as well as (fermenting) plant-derived substrates. In addition, they occupy different niches on and in the human body including the respiratory, gastrointestinal and urogenital tract. As a consequence, lactobacilli have been studied extensively, initially mainly because of their importance for food production. More recently, there is a rapid increase in literature focusing on their occurrence and activity in the human microbiota as well as their use as probiotics, defined as "live microorganisms which when administered in adequate amounts confer a health benefit on the host" (http://www.who.int).

The genus Lactobacillus belongs to the phylum Firmicutes, class Bacilli, order Lactobacillales, and family Lactobacillaceae. A comprehensive review of the taxonomy of lactobacilli summarizes the current taxonomic as well as historic changes [1]. As for many other genera, the taxonomy of lactobacilli has been subject to several changes

\footnotetext{
* Correspondence: r.siezen@cmbi.ru.nl

'Kluyver Centre for Genomics of Industrial Fermentation, NIZO food research, P.O. Box 20, 6710 BA Ede, The Netherlands

Full list of author information is available at the end of the article
}

since the emergence of molecular technologies. At the moment of writing of this review (April 15, 2011), 173 species are recognized, and after removing synonymous species names due to reclassification this can be reduced to 141 species. http://www.bacterio.cict.fr/l/lactobacillus.html.

Many Lactobacillus species are highly specialized and are only found in a limited number of niches. A wellknown example is the species Lactobacillus delbrueckii, which is highly adapted to the dairy environment and widely applied in yoghurt manufacture. Other species, such as Lactobacillus acidophilus, Lactobacillus johnsonii, Lactobacillus reuteri and Lactobacillus rhamnosus are typical inhabitants of the GI tract, and are used in probiotic products [2]. The genome sequence of Lactobacillus iners, a predominant member of the vaginal microbiota, was recently shown to have undergone extensive gene loss, resulting in the smallest Lactobacillus genome reported to date [3].

In contrast, $L$. plantarum is highly versatile and found in many different ecological niches such as vegetables, meat, fish, and dairy products [4-10] as well as in the gastro-intestinal tract [11-13]. Lactobacillus plantarum is a facultative heterofermentative organism that is closely related to Lactobacillus paraplantarum, Lactobacillus pentosus and the recently identified species Lactobacillus fabifermentans[14]. In recent years, an extensive molecular and post-genomics tool box has
Ciomed Central

(c) 2011 Siezen and van Hylckama Vlieg; licensee BioMed Central Ltd. This is an open access article distributed under the terms of the Creative Commons Attribution License (http://creativecommons.org/licenses/by/2.0), which permits unrestricted use, distribution, and reproduction in any medium, provided the original work is properly cited. 
been established for L. plantarum and it has become one of the model micro-organisms in LAB research. This review will in particular focus on the genomic and metabolic diversity of $L$. plantarum. We aim to illustrate that the natural genomic architecture and the metabolic consequences hereof are central to the success of L. plantarum in industrial applications and resemble metabolic engineering strategies applied in synthetic biology.

\section{Lactobacillus plantarum diversity}

Already in the pre-genomic era it was recognized that the phenotypic diversity within the L. plantarum group is very high. A recent phenotypic characterization of 185 isolates from diverse environments showed that isolates from the same food niche or food type phenotypically clustered largely together, but human fecal isolates were scattered throughout different food clusters, suggesting that they generally originate from the food eaten by the individuals [15].

The genetic diversity was initially catalogued by applying molecular approaches including AFLP and RAPD $[13,16,17]$. This work was important in establishing molecular markers to discriminate L. plantarum from L. paraplantarum and L. pentosus, which exhibit highly similar carbohydrate utilization properties and cannot be discriminated by $16 \mathrm{~S}$ rRNA gene sequence analysis. A multilocus sequence-typing (MLST) scheme for this organism was reported which exploits the genetic variation present in six loci of housekeeping genes and can be applied as a molecular tool for identification at the strain level [18](Table 1). Such molecular approaches also revealed the existence of the subspecies $L$. plantarum subsp. argentoratensis, which is most frequently found in fermented plant substrates and can be discriminated in a nested PCR approach [12]. A recent diversity study through comparative genome hybridization with DNA microarrays designed on basis of the genome of L. plantarum WCFS1 confirmed that strains belonging to this subspecies share distinct genomic features and lack two putative extracellular enzyme complexes predicted to be involved in carbohydrate utilization [15].

\section{Applications of Lactobacillus plantarum}

In line with its ability to grow and operate in many different niches, L. plantarum is important for different food and health applications. It is a ubiqitious and often one of the dominant species in foods such as sauerkraut, pickles, olives, sourdough and kimchi [19]. In many of these fermentations $L$. plantarum dominates especially in the later stages of fermentation, presumably because of its high acid tolerance [20,21]. Over the past decade, several groups have focused on the role of L. plantarum in sourdough fermentations, making it one of the best characterized vegetal substrate fermentation processes, as reviewed in depth recently [22]. Meta-transcriptome analysis of sourdough fermentations with DNA microarrays has allowed the global analysis of community dynamics in sourdough fermentations beyond pure populations [23-25]. In these fermentations, L. plantarum appears to be subjected to catabolite repression indicating that it is unlikely to play a major role in the

Table 1 Properties of L. plantarum isolates determined by MLST

\begin{tabular}{|c|c|c|c|c|c|c|c|c|c|c|c|c|c|}
\hline \multirow[b]{2}{*}{ Strain no. } & \multirow[b]{2}{*}{ Strain } & \multirow[b]{2}{*}{ RT } & \multirow[b]{2}{*}{ ITS } & \multirow[b]{2}{*}{ ST } & \multicolumn{6}{|c|}{ Allele no. at locus: } & \multicolumn{3}{|c|}{ Source of isolate } \\
\hline & & & & & pgm & $d d l$ & gyrB & purk1 & gdh & muts & Origin & Country & Year \\
\hline 1 & WCFS1 & ND & ND & 1 & 1 & 1 & 1 & 1 & 1 & 1 & Human saliva & UK & 1956 \\
\hline 2 & CECT 220 (ATCC 8014) & 1 & 1 & 2 & 1 & 3 & 1 & 2 & 6 & 5 & Corn silage & ND & 1948 \\
\hline 3 & CECT 221 (ATCC 14431) & 2 & 1 & 3 & 1 & 1 & 6 & 3 & 8 & 1 & Grass silage & ND & 1960 \\
\hline 4 & CECT 223 & 2 & 1 & 4 & 1 & 5 & 3 & 4 & 7 & 1 & ND & Pamplona, Spain & 1987 \\
\hline 5 & CECT 224 & 2 & 1 & 4 & 1 & 5 & 3 & 4 & 7 & 1 & ND & Pamplona, Spain & 1987 \\
\hline 6 & CECT $748^{\top}$ (ATCC 14917) & 2 & 1 & 5 & 3 & 2 & 1 & 2 & 1 & 1 & Pickled cabbage & Denmark & 1919 \\
\hline 7 & CECT 749 (ATCC 10241) & 2 & 1 & 6 & 3 & 2 & 1 & 2 & 3 & 1 & Pickled cabbage & ND & 1955 \\
\hline 8 & CECT 4185 (NCBF 1193) & 2 & 1 & 7 & 3 & 1 & 2 & 1 & 5 & 1 & Silage & ND & 1958 \\
\hline 9 & CECT 4645 (NCBF 965) & 4 & 1 & 8 & 2 & 4 & 7 & 8 & 10 & 4 & Cheese & ND & 1958 \\
\hline 10 & $\mathrm{RM} 28$ & 2 & 1 & 9 & 1 & 2 & 1 & 7 & 7 & 3 & Wine & Valladolid, Spain & 2000 \\
\hline 11 & RM35 & 4 & 1 & 10 & 3 & 2 & 1 & 2 & 2 & 8 & Wine & Toledo, Spain & 1998 \\
\hline 12 & RM38 & 2 & 1 & 11 & 3 & 1 & 4 & 2 & 4 & 2 & Wine & Toledo, Spain & 1998 \\
\hline 13 & RM40 & 3 & 1 & 12 & 1 & 1 & 1 & 5 & 9 & 1 & Wine & Toledo, Spain & 1998 \\
\hline 14 & RM71 & 2 & 1 & 13 & 3 & 1 & 5 & 6 & 5 & 6 & Wine & Valladolid, Spain & 2001 \\
\hline 15 & $\mathrm{RM} 72$ & 2 & 1 & 13 & 3 & 1 & 5 & 6 & 5 & 6 & Wine & Valladolid, Spain & 2001 \\
\hline 16 & RM73 & 2 & 1 & 14 & 3 & 2 & 1 & 2 & 1 & 7 & Wine & Madrid, Spain & 2000 \\
\hline
\end{tabular}

RT, Ribotype; ITS, 16S-23S ISR type; ST, sequence type; ND, no data available.

Reprinted from [18] with permission from the Society for General Microbiology Ltd. 
utilization of maltose. Other groups have highlighted the importance of intra- and inter-species communication with a specific focus on communication between $L$. plantarum and $L$. sanfranciscencis strains. Quorum sensing communication involving $p \ln A$ - and $l u x S$ dependent pathways invoked multiple regulatory responses that directly influence community dynamics as well as the activity of community members [26].

L. plantarum is also applied as a probiotic. Over the last decade there have been a growing number of studies aimed at deciphering the potential beneficial effects of L. plantarum strains on human health [27]. Strain L. plantarum $299 \mathrm{v}$ is marketed as a probiotic and a number of clinical intervention studies have been published, as reviewed by $[28,29]$. Interestingly, transcriptome analysis using ileal and colonic biopsies from human intervention studies with this strain revealed that it specifically adapts its metabolic capacity in the human intestine for carbohydrate acquisition and expression of exopolysaccharide and proteinaceous cell-surface compounds [30]. In return, interventions with strain L. plantarum WCFS1 were shown to exert distinct and reproducible transcriptional responses in duodenal mucosal biopsies. Consumption of live L. plantarum bacteria in different growth phases revealed striking differences in modulation of NF- $\kappa \mathrm{B}$-dependent pathways [31]. These observations shed new light on the molecular cross-talk between ingested L. plantarum and the host, although the relevance to host health remains to be established.

\section{Genome sequencing}

Detailed molecular and transcriptomics studies are only possible when the genome sequences are available. The genome of $L$. plantarum strain WCFS1, a single colony isolate of strain NCIMB8826 that was originally isolated from human saliva, was the first to be fully sequenced, and it was in fact the first of any Lactobacillus genomes to be published [32]. It consists of a $3.3 \mathrm{Mb}$ chromosome, still the largest of any sequenced lactic acid bacteria to date, and three plasmids of $1.9 \mathrm{~kb}, 2.3 \mathrm{~kb}$ and $36.1 \mathrm{~kb}$ (Table 2). A variety of bioinformatics tools has since been used to predict function of genes and gene clusters [33-35], to reconstruct metabolic pathways [36-39], to reconstruct regulatory networks [40-42], to compare with genomes of other lactic acid bacteria [43-45], and to store and visualize these results in a user-friendly way [46]. The genome of the original WCFS1 strain has recently been resequenced using Illumina technology, revealing nearly 100 SNPs and indels, and fully re-annotated (Siezen, Francke, Boekhorst, Renckens, Kleerebezem, van Hijum, unpublished data). This small number $(0.003 \%)$ of nucleotide corrections detected using modern highthroughput Illumina sequencing technology emphasizes that the original sequencing 10 years ago using Sanger technology was very thorough [32].

The flexible and adaptive behaviour of L. plantarum was first found to be reflected in the chromosome of strain WCFS1, which encodes a large variety of proteins involved in sugar uptake and utilization, and accompanying regulatory proteins [32]. This allows the organisms to grow on numerous carbon sources as it includes 25 complete PTS enzyme II complexes, several incomplete PTS complexes, and another 30 transport systems predicted to transport various carbohydrates; the genes encoding transporters are usually in gene cassettes clustered with genes encoding enzymes and regulatory proteins involved in sugar metabolism.

The chromosome also encodes over 200 putative extracellular proteins, most of which should be displayed at the cell surface, as they are predicted to be bound to cellenvelope components in several ways $[33,35,44,45]$. Some of these extracellular proteins are also encoded in specific gene cassettes (e.g. the csc genes [33]), and their primary occurrence in plant-associated gram-positive bacteria suggests a possible role in degradation and utilization of plant oligo- or poly-saccharides. This large number of surface-bound extracellular proteins is also likely to contribute to the large flexibility in interactions with its environment.

It was hypothesized that the L. plantarum WCFS1 chromosome contains specific regions that are dedicated to interactions with the environment, designated life-style adaptation regions. These regions are clustered near the origin of replication, exemplified by the region between 3.0 and $3.3 \mathrm{Mb}$ which includes a large proportion of the sugar utilization cassettes as well as genes encoding extracellular functions [32]. This entire region has a lower GC content ( $41.5 \%$ vs $44.5 \%$ for the whole chromosome), and many of these genes display deviation of nucleotide composition, consistent with a foreign origin. Thus, based on this single genome sequence, it was suggested that $L$. plantarum has lifestyle adaptation regions that could be "used to effectively adapt to the changes in conditions encountered in the numerous environmental niches in which this microbe is found" [32].

\section{Genome diversity analysis based on whole genomes by comparative genome hybridization (CGH)}

The genomic diversity of $L$. plantarum on a full genome scale was analyzed by CGH in two separate studies $[15,47]$. The presence or absence of genes relative to the reference strain WCFS1, of which DNA was spotted on microarrays, was assessed by hybridization of DNA from 19 [47] and 41 other L. plantarum strains [15] isolated from a large variety of environmental niches, ranging from fermented milk, vegetable, fruit and meat products to human isolates (intestine, saliva, faeces, spinal fluid, urine, 
Table 2 Summary of sequenced genomes of Lactobacillus plantarum strains

\begin{tabular}{|c|c|c|c|c|c|c|}
\hline & WCFS1 & JDM1 & ST-III & ATCC 14917 & NC8 & KCA1 \\
\hline $\begin{array}{l}\text { Genome } \\
\text { size (bp) }\end{array}$ & $3,308,274$ & $3,197,759$ & $3,254,376$ & $\sim 3.2 \mathrm{Mb}$ & $\sim 3.2 \mathrm{Mb}$ & $\sim 3.4 \mathrm{Mb}$ \\
\hline contigs & 1 & 1 & 1 & 36 & 67 & 84 \\
\hline GC\% & 44.5 & 44.7 & 44.6 & 44.0 & 45.0 & 45.3 \\
\hline CDS & 3007 & 2948 & 2996 & 3154 & $\sim 3000$ & $\sim 3200$ \\
\hline plasmids & 3 & 2 & 1 & $?$ & $?$ & 0 \\
\hline $\begin{array}{l}\text { Accession } \\
\text { code }\end{array}$ & NC_004567 & CР001617 & NC_014554 & NZ_ACGZ02000000 & & \\
\hline source & $\begin{array}{l}\text { human } \\
\text { saliva }\end{array}$ & $\begin{array}{l}\text { grass } \\
\text { silage? }\end{array}$ & kimchi & pickled cabbage & grass silage & human vagina \\
\hline reference & [32] & {$[50]$} & [51] & $\begin{array}{l}\text { Human Genome Sequencing Center, Baylor College of } \\
\text { Medicine, Houston, Texas, USA }\end{array}$ & $\begin{array}{l}\text { Axelsson et al, } \\
\text { unpublished }\end{array}$ & $\begin{array}{l}\text { Anukam et al, } \\
\text { unpublished }\end{array}$ \\
\hline
\end{tabular}

teeth). In the first study [47], the probes on the microarray consisted of a subset of genomic fragments amplified by PCR from the random insert library used for initial sequencing of the L. plantarum WCFS1 genome; this microarray covered only $81 \%$ of all bases of the WCFS 1 genome. The presence or absence of genomic fragments (and encoded genes) in the 19 query strains corresponding to the clones on the array was inferred from a statistical model. In the second study [15], an ORF-based DNAmicroarray of L. plantarum WCFS1 was used, in which most ORFs were represented by at least three specific oligomer probes, evenly distributed over the gene sequence. This allowed a higher coverage of the genome content and higher resolution analysis of individual gene content in the genomes of 41 other L. plantarum strains. It must be stressed that this $\mathrm{CGH}$ analysis could only detect presence or absence of genes relative to the single reference genome of strain WCFS1, and did not provide information on additional genes not present in the reference strain, nor did it allow conclusions about the chromosomal location of genes (i.e. gene order). These $\mathrm{CGH}$ genotyping results can be displayed as "bar plots" with the chromosomal organization of strain WCFS1 as template, in which a black bar indicates the absence of a gene in a specific strain (Fig. 1). Based on their hybridizations profiles, a distance matrix representing fractional genotype similarity between strains can be constructed, and shown in a hierarchical tree. These bar plots clearly show hot spots with high variability amongst strains, and many of these hot spots, but not all, correspond to regions of high basedeviation index, suggestive of horizontal gene transfer.

All tested L. plantarum strains were predicted to lack 9-20\% of the genes of the reference genome L. plantarum WCFS1, and about 50 genes appeared to be specific for strain WCFS1, as they were not found in any other strain [15]. The predicted absence of genes appeared to occur mainly as functional gene clusters, or cassettes, often organized in operons $[15,47]$. These cassettes encode known functions such as i) prophages, ii) restriction-modification, iii) exopolysaccharide biosynthesis, iv) bacteriocin and non-ribosomal peptide biosynthesis, and v) carbohydrate utilization. Three large cassettes, encoding macrolide biosynthesis, non-ribosomal peptide biosynthesis (NRPS) and exopolysaccharide biosynthesis (EPS), were only found in strain WCFS1 and have a distinctly lower GC content; presumably they have been acquired by recent horizontal gene cassette transfer.

Particularly apparent was that the proposed lifestyle adaptation regions with high density of encoded surface proteins and sugar utilization proteins, initially predicted from only the single genome of strain WCFS1 [32], were indeed found to be highly variable in other strains (green arrows in Fig. 1), supporting the hypothesis that life-style adaptation is focused in these regions. A closer inspection of the variable sugar life-style region on the chromosome (from 3.07-3.28 Mb, genes lp_3468-1p_3657) shows that there are many consecutive cassettes of 3-10 genes which are predicted to be involved in utilization of different sugars (Additional file [1]) These sugar utilization cassettes usually represent complete functional units, encoding a transporter (permease, PTS or ABC-type), a regulator and enzymes for metabolizing the sugar (Figure 2A). Most cassettes are not unique to $L$. plantarum, but can be found in various other lactobacilli (Figures $2 \mathrm{~B}, 2 \mathrm{C}$ ) or other bacteria (data not shown). The huge variability of these functional cassettes confirms the enormous flexibility of L. plantarum to adapt to different environments and growth substrates.

\section{Gene-trait matching}

A web-tool - PhenoLink - has been developed that facilitates associating bacterial phenotypes to $\sim$ omics data (J. Bayjanov, D. Molenaar, R.J. Siezen, S.A.F.T. van Hijum, submitted for publication). This tool uses a Random Forest algorithm $[48,49]$ which builds an ensemble of decision trees to classify huge data sets. This classification method allowed identification of correlations between genotypes (i.e. presence/absence of genes based 


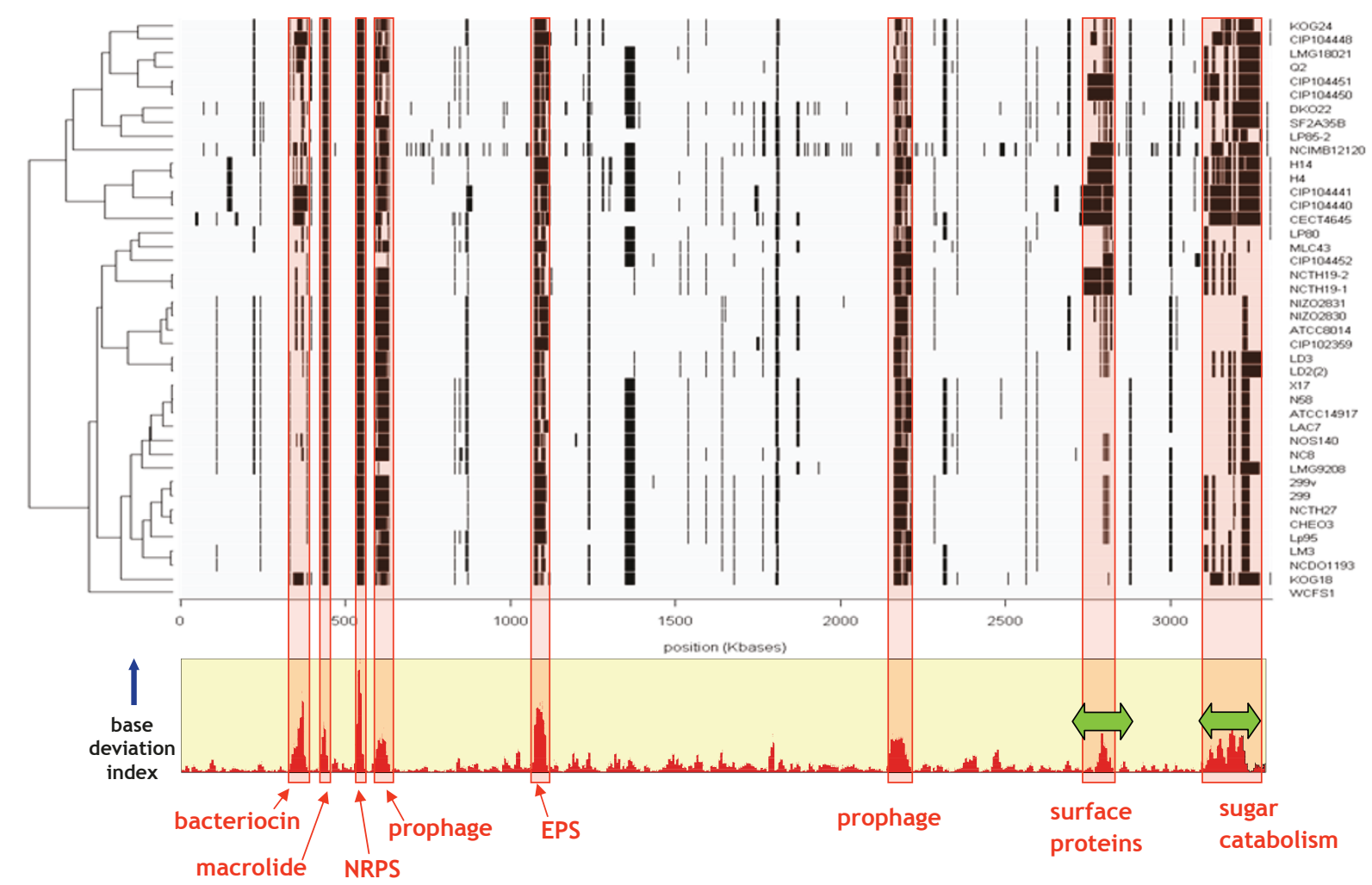

Figure 1 Comparative genome hybridization (CGH) analysis of $L$. plantarum isolates. The genes are ordered based on their location in the genome sequence of L. plantarum WCFS1 (horizontal axis). Black bars indicate "absent" genes/regions. Red boxes indicate regions where large differences in presence/absence of genes correspond with a high base-deviation index. Adapted from Figure 2 of [15], with permission from the Society for Applied Microbiology and Blackwell Publishing Ltd.

on $\mathrm{CGH}$ ) and phenotypes (i.e. growth on carbohydrates, $\mathrm{NO}_{2}$ production and stress tolerance) of these 42 Lactobacillus plantarum strains (J. Bayjanov, D. Molenaar, R.J. Siezen, S.A.F.T. van Hijum, submitted for publication).

Examples of preliminary correlations found for some gene cassettes involved in sugar utilization are shown in Figure 3 (courtesy of J. Bayjanov). The 42 strains were tested for growth or no growth on a variety of sugars [15] and the Random Forest algorithm was used to detect correlations with presence or absence of gene clusters. Four gene cassettes are shown which were originally annotated with functions involved in uptake and metabolism of arabinose, rhamnose, myo-inositol and sorbitol [32]. The first cassette (lp_3549-3558) indeed perfectly correlates with the growth on arabinose phenotype, i.e. the gene cluster is present in strains that grow, and absent in strains that do not grow on L-arabinose. However, this gene cluster also correlates with growth on D-sorbitol and K-gluconate, suggesting that these genes may also be involved in metabolizing alternative sugars. The presence of the rhamnose gene cassette (lp_3591-3598) also correlates with growth on L-arabinose and K-gluconate, suggesting that these genes could also be involved in growth on these sugars. Finally, the putative gene clusters for myo-inositol (lp_3604-3615) and sorbitol (lp_36193622 ) utilization are found to correlate with growth on D-arabitol (and not D-sorbitol), suggesting their annotation is too specific and that these systems may be involved in metabolism of various different sugar alcohols.

A preliminary conclusion from this gene-trait matching is that it is not easy to find correlations between phenotypes and genotypes, even with sophisticated algorithms, as both the phenotype and genotype data are inherently noisy. Moreover, classifying genes as present/absent using CGH data based on a single reference genome clearly has its limitations. As shown below, the recently sequenced genomes of other L. plantarum strains now provide clues as to why this is the case. On the other hand, the Random Forest methods are able to provide many new leads for the putative function of genes and gene clusters that can be tested experimentally. The examples above already suggest that multiple phenotypes can be linked to a single gene cluster, and vice versa. 


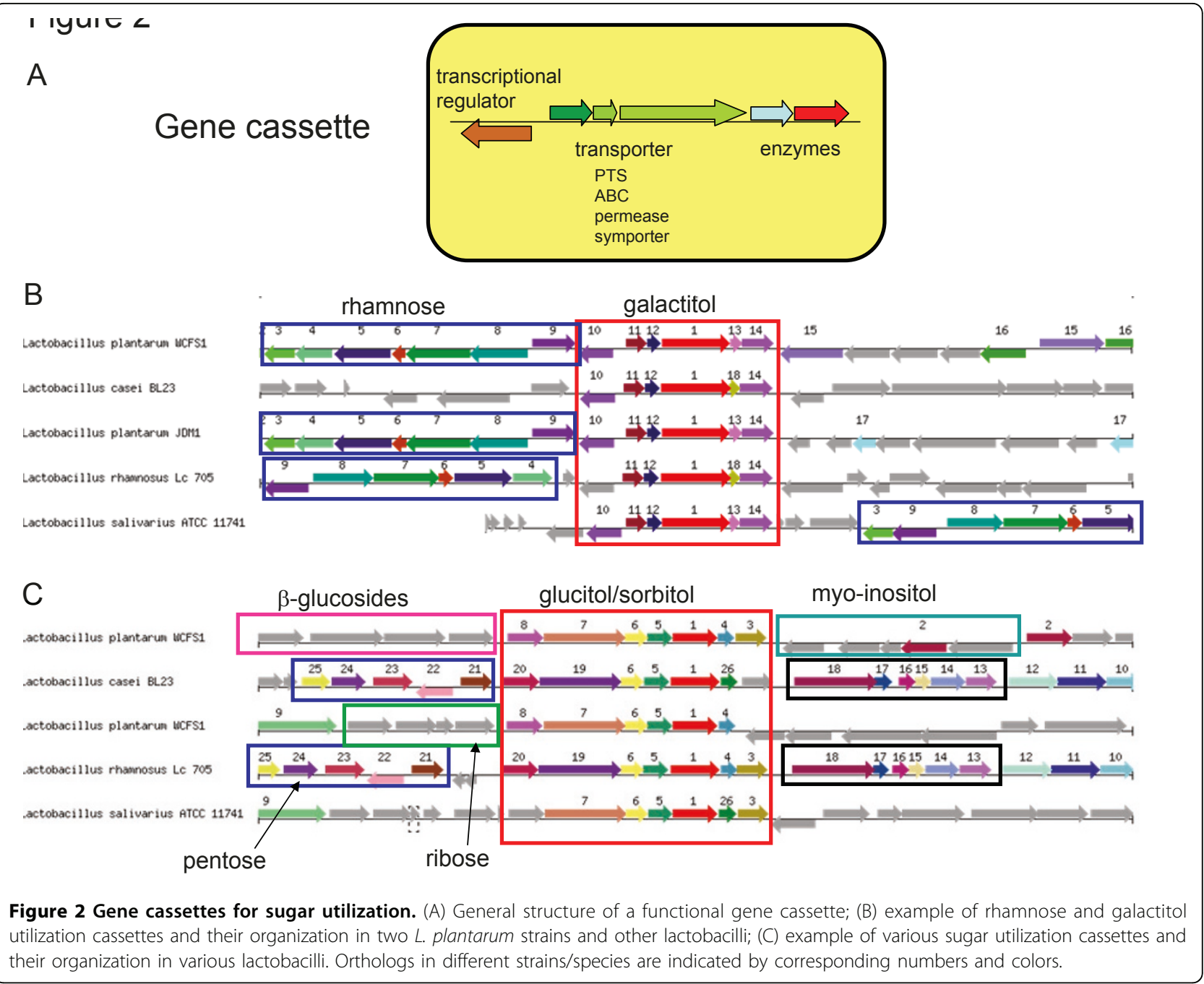

\section{Comparative genomics of 6 sequenced Lactobacillus plantarum strains}

Complete genome sequences have now been published for L. plantarum strains WCFS1 [32], JDM1 [50] and ST-III [51], and the draft genome sequence of type strain L. plantarum ATCC14917 is available in Genbank (accession code NZ_ACGZ02000000). Two additional draft genome sequences are available from strains $\mathrm{NC} 8$ and KCA1 (Table 2). An extensive comparative analysis of these six genomes has been performed, providing detailed insight into core genes, variable or accessory genes and gene cassettes, genome synteny, transposable elements, and functional adaptation to growth on various substrates (Siezen, Anukam, Axelsson, Francke, Boekhorst, Renckens, Kleerebezem, van Hijum, unpublished data). Some preliminary conclusions and examples will be presented below.

\section{Comparison of CGH vs. genome sequences}

Three strains of the six sequenced genomes were previously included in the $\mathrm{CGH}$ analysis, i.e. strains WCFS1,
ATCC14917 and NC8 [15]. This allowed a validation of the accuracy of the CGH analysis. The full genome sequences show that several genes are actually present that were classified as absent by CGH (false negatives); the majority of these are in the highly variable gene clusters for prophages, plantaricin and EPS biosynthesis (see below). The main reason for missing these genes by CGH is that the percentage identity of nucleotide sequence for certain genes or even gene cassettes is too low for hybridization on the microarray (Siezen, Anukam, Axelsson, Francke, Boekhorst, Renckens, Kleerebezem, van Hijum, unpublished data). The cut-off for reliable gene detection by hybridization appears to be at an overall $80-90 \%$ nucleotide sequence identity of genes, but this will also depend on the choice of probe positions (three 60-mer probes were used for most genes in the CGH experiment [15]).

An example of genes missed by CGH is the tarIJKL gene cluster, encoding wall teichoic acid biosynthesis proteins. Tomita et al [52] sequenced the teichoic acid 


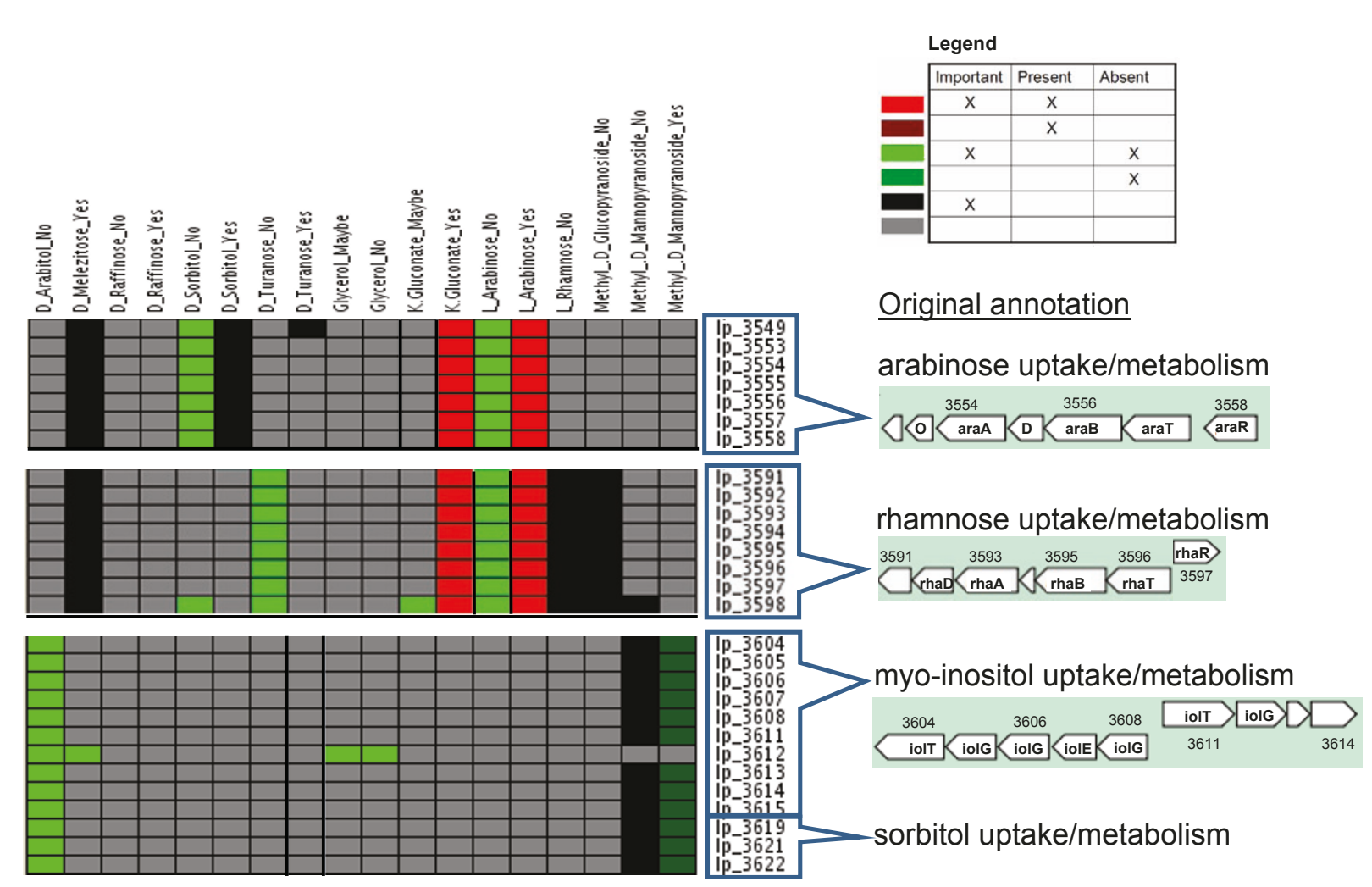

Figure 3 Genotype-phenotype linkage analysis by Random Forest classification. Growth (Yes) or non-growth (No) of 42 different L. plantarum strains on a variety of sugars was measured. Legend: the color coding used for integration of significance of genes for a certain phenotype with their presence/absence patterns for the different strains. A gene that is found to be important to distinguish strains of different phenotypes is assumed as important. Present (for the majority of strains): gene is present in at least $p$ percent (default of $75 \%$ ) of strains for a given phenotype. Absent (for the majority of strains): gene is absent in at least $75 \%$ of strains of a given phenotype. Examples are given of gene cassettes (using gene numbering of strain WCFS1) that are found to be important for phenotype classification of strains.

biosynthesis genes (clusters of 3 and 4 genes) in 18 L. plantarum strains, compared these with strain WCFS1 and found two sequence variants which correlate with glycerol-type and ribitol-type teichoic acids. The full genomes now show that these tar genes are nearly identical in strains JDM1, ATCC14917, ST-III, NC8 and KCA1, but show only $69-74 \%$ nucleotide sequence identity to the tarIJK genes of strain WCFS1 (see Figure 4), and hence were missed by the CGH analysis using WCFS1 as the reference.

\section{Diversity of gene cassettes}

In general, there is very high conservation of gene order (synteny) in the six sequenced chromosomes of the L. plantarum strains, and in sequence identity of orthologs. However, there are several highly variable regions in the chromosome which deviate from this rule, and some examples are given below.

\section{Highly variable cassettes}

- Prophages, IS elements and transposases: As expected, the cassettes encoding prophages and transposases (of
IS elements) are highly variable, both in gene content and in position of insertion in the chromosomes. Details will be described in (Siezen, Anukam, Axelsson, Francke, Boekhorst, Renckens, Kleerebezem, van Hijum, unpublished data).

- Plantaricin biosynthesis genes. The plantaricin (pln) gene cluster of L. plantarum of about 25 genes (Figure $5)$, encodes the biosynthesis of various class IIb bacteriocins, whose full activity depends on the action of two different peptides $[53,54]$. The $p l n$ gene cluster has been previously sequenced from six $L$. plantarum strains (including WCFS1 and NC8) and found to be a highly variable and mosaic region, with parts being relatively conserved and other parts less conserved $[55,56]$. A PCR analysis directed to 27 genes of this pln cluster in $33 \mathrm{~L}$. plantarum strains of oenological origin found even more variation and led to a subdivision into seven groups, named plantaritypes [56]. The six fully sequenced genomes (Table 2) show the same high variability, but also demonstrate that the conservation and synteny of genes flanking the $p l n$ locus is 


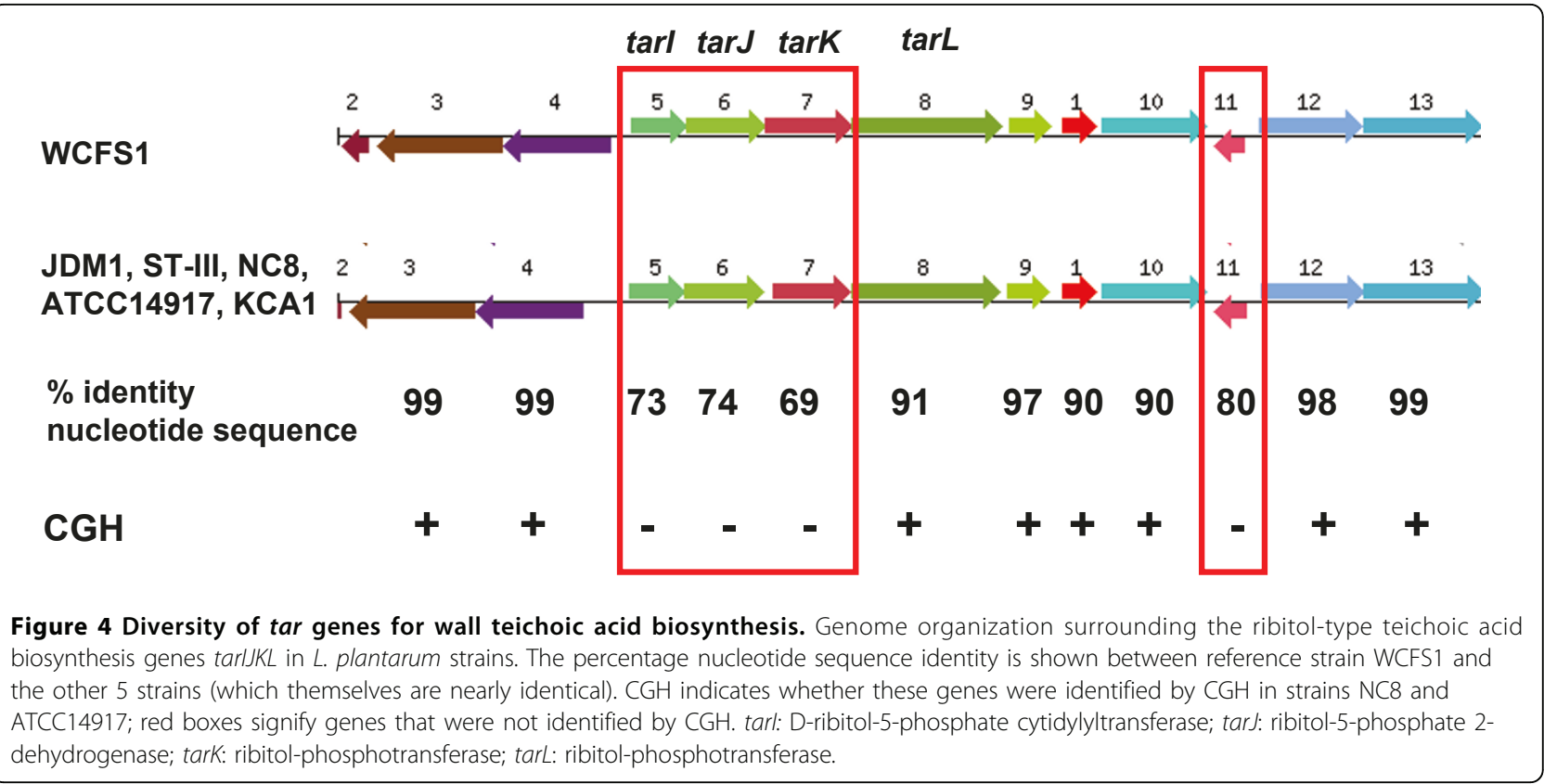

very high (Siezen, Anukam, Axelsson, Francke, Boekhorst, Renckens, Kleerebezem, van Hijum, unpublished data).

- CPS/EPS biosynthesis genes. The chromosome of strain WCFS1 has 3 consecutive cps clusters (cps1, cps2, cps3), separated by transposase genes (and their fragments), encoding proteins involved in biosynthesis and export of extracellular or capsular polysaccharides. At the same position in the chromosome, the other 5 sequenced genomes also have cps clusters (Figure 6). Some parts of these clusters are shared, but many parts contain completely different cps genes. The cps 1 cluster of strain WCFS1 is not present in any of the other sequenced genomes, while the cps 3 cluster and parts of the cps 2 cluster are shared by 4 strains, but lacking in JDM1. This high variability presumably leads to variation in the structure of capsular and exopolysaccharides. A similar variability of EPS gene cassettes has been observed in other LAB [57-62].

\section{Life-style cassettes}

The enormous variability of cassettes in the sugar lifestyle region deduced from CGH analysis (Additionl file [1]) $[15,47]$ led to the hypothesis ".... that similar lifestyle adaptation islands will exist in other strains of L. plantarum. This would also imply that these strains contain a high number of genes with related functions accumulated within their lifestyle adaptation region that are absent from the WCFS1 genome." [47].

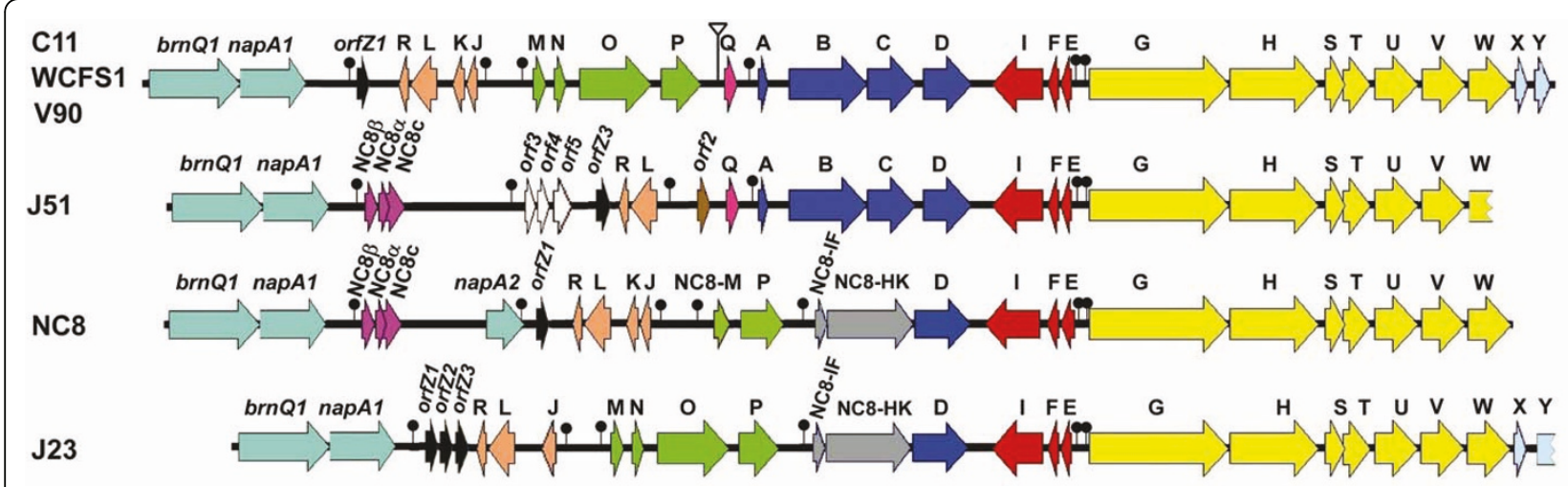

Figure 5 Diversity of plantaricin (p/n) gene clusters. Mosaic pln loci from strains of Lactobacillus plantarum. Lollipops indicate regulated promoters. The genes brnQ1 and napAl at the upper end of the pln loci are not part of the pln regulon but they are included in the gene map to signify the upper boundary of the pln locus. Note that the lower ends of the pln loci of J51, NC8 and J23 are not completely sequenced. Reproduced from [55], with permission from Elsevier Inc. 


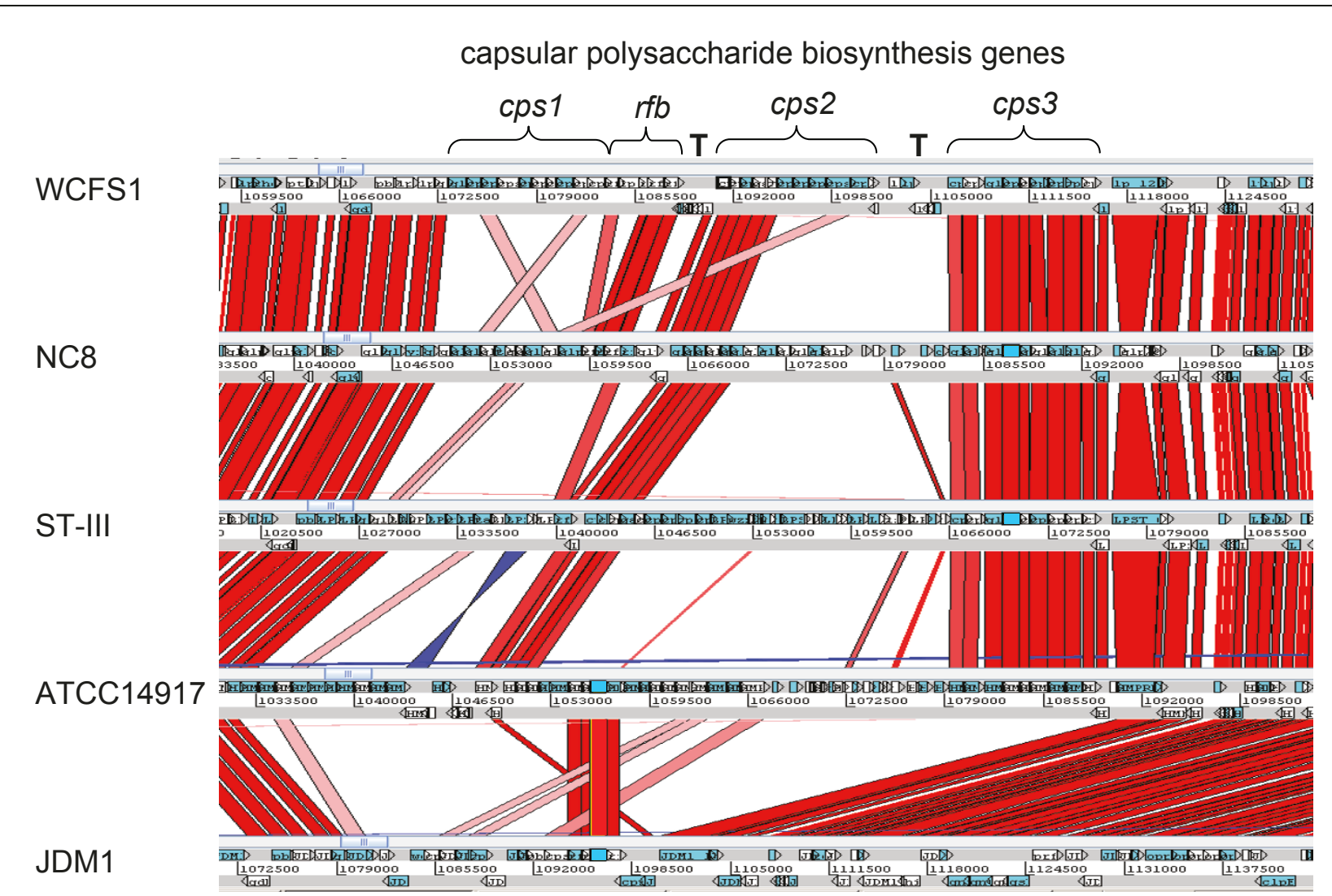

Figure 6 Diversity of capsular polysaccharide biosynthesis genes. Comparison of genome organization surrounding the large cluster of cps biosynthesis genes. Genes are represented by blue and white arrows, in forward and reverse strands. Shades of connecting bars indicate high sequence identity (bright red) to low sequence identity (pink). The blue connecting bar indicates a reverse orientation. The 3 consecutive cps gene clusters in WCFS1 are indicated, and the rfbACBD genes. T indicates transposases of IS elements. Picture drawn with Artemis Comparison Tool (ACT)[66].

Comparison of the 6 sequenced genomes now shows that indeed many novel cassettes are present in these variable regions that are absent in strain WCFS1 (Siezen, Anukam, Axelsson, Francke, Boekhorst, Renckens, Kleerebezem,van Hijum, unpublished data). A typical example is shown in Figure 7, representing the diversity of cassettes in a small part of the life-style region corresponding to genes lp_3114-lp_3150 (from 2.78-2.82 Mb on the chromosome) in strain WCFS1. In addition to the five known cassettes present in strain WCFS1, another five novel cassettes are found in the other sequenced strains, and these would not have been detected in the original CGH analysis using only WCFS1 as a reference. Strains WCFS1 and ATCC14917 share the same 5 cassettes, and strains NC8 and ST-III share a different set of 5 cassettes, while 3 cassettes are unique to strain KCA1. Cassette 5 encoding putative cellobiose utilization appears to replace cassette 4 encoding $\beta$-glucosides utilization at the same position in the chromosome.

\section{Diversity at single gene/protein level}

Diversity between strains is even seen within L. plantarum genes and proteins at the level of numbers of repeated domains or motifs, particularly in extracellular proteins, again suggesting variability between strains in interactions with their environment.

One published example is an extracellular, peptidoglycan-bound mannose-specific adhesin (msa gene; lp_1229 in strain WCFS1) which has variations in the number of mucus-binding (Mub) domains and PxxP spacer motifs in different strains, which could relate to differences in mucus-binding efficiency [63] (Figure 8). Another example is a very large extracellular, membrane-anchored protein (encoded by lp_1303a in strain WCFS1) of unknown function that has a middle domain with hundreds of repeats of SD (Ser-Asp); possibly the Ser residues are glycosylated by glycosyl transferases [32], as three adjacent genes in the L. plantarum genomes encode putative glycosyl transferases. The N-terminal domain (includes signal peptide) and C-terminal domain (includes membrane anchor) are 


\section{gene cassettes}

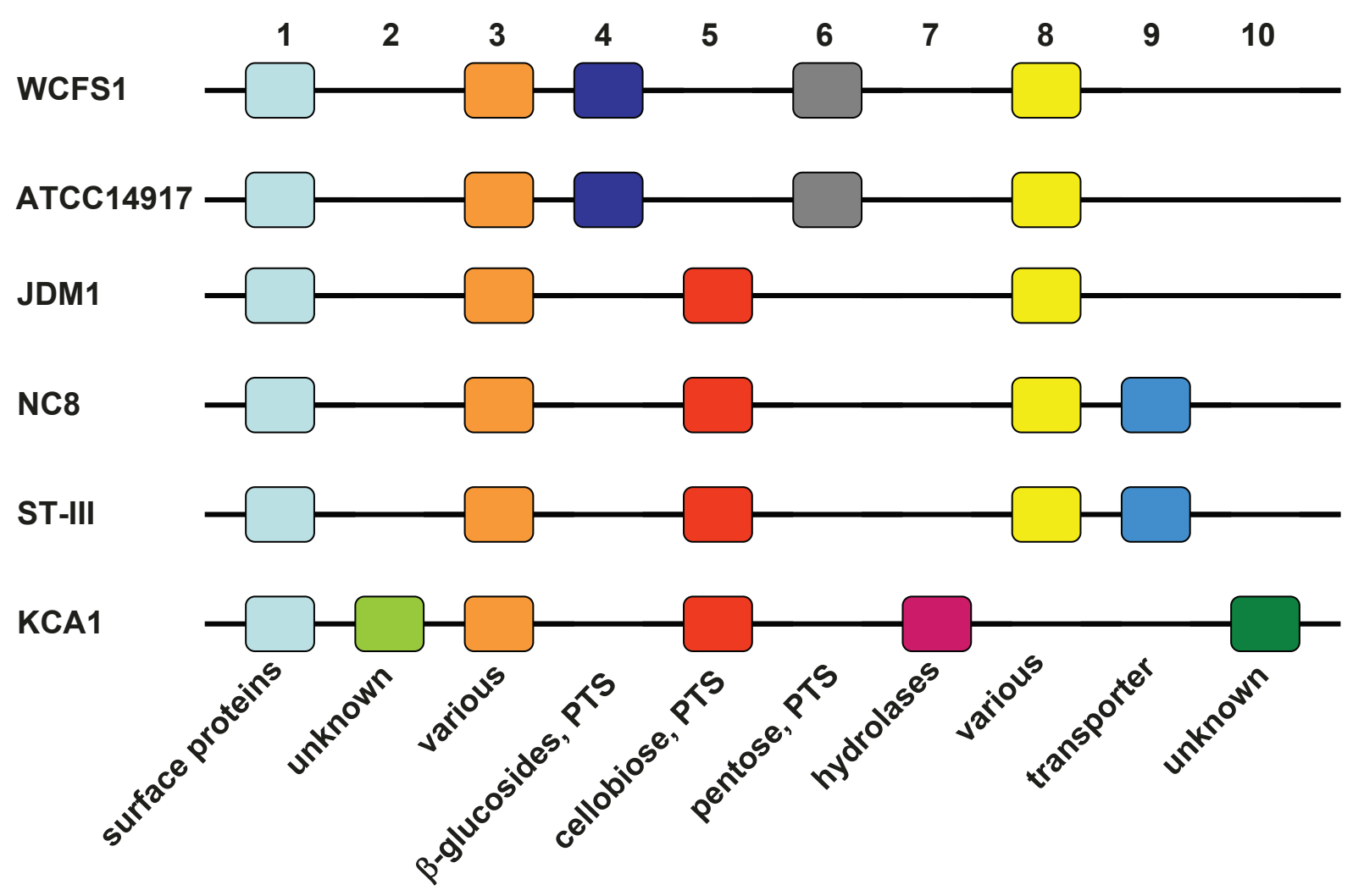

Figure 7 Modularity and variability of life-style gene cassettes. Life-style region corresponding to genes Ip_3114-Ip_3150 (from 2.78-2.82 $\mathrm{Mb}$ on the chromosome) in strain WCFS1, represented as gene cassettes. Each cassette contains 3-18 genes (see example in Figure 2A); identical colors indicate corresponding cassettes in other strains. Putative functions of proteins encoded in the cassettes are indicated.

nearly identical in this protein from all sequenced L. plantarum strains, but there is a large variation in the number of SD repeats ranging from 242 repeats in strain JDM1 to 801 repeats in strain WCFS1.

\section{Conclusions}

Genome sequencing and comparative genomics of L. plantarum has revealed a high genomic diversity, versatility and flexibility which are at the heart of its success in diverse niches and applications. One of the most striking observations is the occurrence of genomic islands harboring mosaic modules or cassettes of carbohydrate utilization genes, likely acquired through horizontal gene transfer. Many of these cassettes are also found in other LAB (see for instance Figure 2) and other gram-positive bacteria. L. plantarum seems to be a master in acquiring and shuffling these cassettes, but it cannot be excluded that this shuffling propensity is also linked with other gram-positive bacteria. By its ability to acquire and assemble gene cassettes required for the utilization of carbohydrates, L. plantarum seems to have developed a "natural metabolic engineering approach" that allows it to optimize its genome for growth in specific niches, especially those rich in plant carbohydrates. In that aspect, there are interesting synergies with the approaches applied nowadays in metabolic engineering for biofuels production. The cellular traits and catabolic capacities that are sought when constructing biofuels-producing $S$. cerevisiae and E. coli are prospected in nature, introduced into the host and subsequently optimized through advanced molecular and evolutionary engineering strategies [64].

It seems likely that in $L$. plantarum there could be an important role in this respect for diversity generating molecular structures such as (conjugative) plasmids, IS elements and transposons. To date, experimental data showing that transfer of such elements is an effective means to increase the catabolic potential of lactic acid bacteria are scarce. Recently, it was shown that conjugative transfer of transposon Tn6098 encoding alpha-galactosides metabolism in 


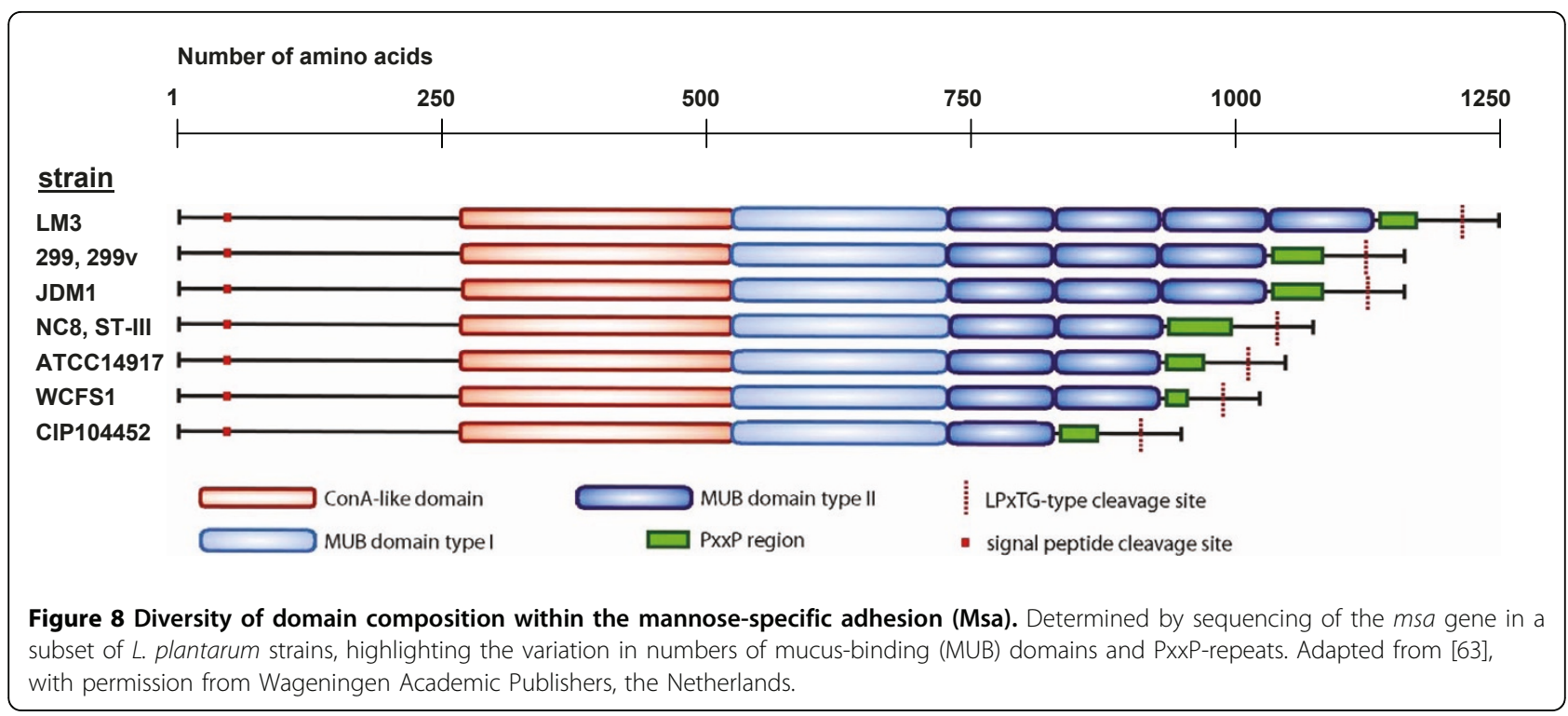

Lactococcus lactis enable a dairy isolate to grow in soy milk, a substrate rich in $\alpha$-galactosides [65]. On the other hand, the numerous cassettes in L. plantarum appear to be directly linked to each other, with no evidence of flanking or intervening elements from plasmids or IS elements. Further investigation into the molecular mechanisms by which $L$. plantarum is able to acquire and assemble such gene cassettes encoding functional pathways into its chromosome should therefore be of importance to learn how to harness this natural metabolic engineer.

\section{Additional material}

Additional file 1: Diversity in presence/absence of gene clusters in $42 \mathrm{~L}$. plantarum strains in part of the sugar life-style island region, according to CGH analysis.

\section{List of abbreviations used}

ABC: ATP-binding cassette; ACT: Artemis comparison tool; AFLP: amplified fragment-length polymorphism; CGH: comparative genome hybridization; CPS: capsular polysaccharide; EPS: extracellular polysaccharide; GC: guanine \& cytosine; LAB: lactic acid bacteria; IS: insertion sequence; MLST: multi-locus sequence typing; ORF: open-reading frame; PCR: polymerase chain reaction PTS: phospho-transferase system; RAPD: random amplification of polymorphic DNA; SNP: single nucleotide polymorphism.

\section{Acknowledgements}

We sincerely thank Lars Axelsson and Kingsley Anukam for sharing thei unpublished genome sequence data of strains NC8 and KCA1, respectively, prior to publication. We thank all co-author colleagues of our original and forthcoming papers on L. plantarum sequencing and diversity analysis, and in particular Michiel Kleerebezem, Douwe Molenaar, Giovanna Felis, Christof Francke, Sacha van Hijum, Michiel Wels, Bernadet Renckens, Jos Boekhorst, and Juma Bayjanov.

This work was supported by a BSIK grant through the Netherlands Genomics Initiative (NGI) and was part of the BioRange programme of the Netherlands Bioinformatics Centre (NBIC). Additional funding was obtained from NGl as part of the Kluyver Centre for Genomics of Industrial Fermentation.

This article has been published as part of Microbial Cell Factories Volume 10 Supplement 1, 2011: Proceedings of the 10th Symposium on Lactic Acid Bacterium. The full contents of the supplement are available online at http:// www.microbialcellfactories.com/supplements/10/S1.

\section{Author details}

${ }^{1}$ Kluyver Centre for Genomics of Industrial Fermentation, NIZO food research, P.O. Box 20, 6710 BA Ede, The Netherlands. ${ }^{2}$ Centre for Molecular and Biomolecular Informatics, NCMLS, Radboud University Medical Centre, PO Box 9101, Nijmegen, the Netherlands. ${ }^{3}$ TI Food and Nutrition, P.O. Box 557 6700 AN Wageningen, The Netherlands. ${ }^{4}$ Netherlands Bioinformatics Centre, 260 NBIC, P.O. Box 9101, 6500 HB Nijmegen, the Netherlands. ${ }^{5}$ Danone Research, R.D. 128, Avenue de la Vauve, F-91767 Palaiseau Cedex, France.

\section{Authors' contributions}

RJS conceived the review and gathered, restructured and analyzed data. RJS and JHV jointly drafted and wrote the manuscript.

\section{Competing interests}

The authors declare they have no competing interests.

Published: 30 August 2011

\section{References}

1. Felis GE, Dellaglio F: Taxonomy of Lactobacilli and Bifidobacteria. Curr Issues Intest Microbiol 2007, 8(2):44-61.

2. Siezen RJ, Wilson G: Probiotics genomics. Microb Biotechnol 2010, 3(1):1-9.

3. Macklaim JM, Gloor GB, Anukam KC, Cribby S, Reid G: At the crossroads of vaginal health and disease, the genome sequence of Lactobacillus iners AB-1. Proc Natl Acad Sci U S A 2011, 108(Suppl 1):4688-4695.

4. Gardner NJ, Savard T, Obermeier P, Caldwell G, Champagne CP: Selection and characterization of mixed starter cultures for lactic acid fermentation of carrot, cabbage, beet and onion vegetable mixtures. Int J Food Microbiol 2001, 64(3):261-275.

5. Ercolini D, Hill PJ, Dodd CE: Bacterial community structure and location in Stilton cheese. Appl Environ Microbiol 2003, 69(6):3540-3548.

6. Aryanta RW, Fleet GH, Buckle KA: The occurrence and growth of microorganisms during the fermentation of fish sausage. Int $\mathrm{J}$ Food Microbiol 1991, 13(2):143-155.

7. Mundt JO, Hammer JL: Lactobacilli on plants. Appl Microbiol 1968, 16(9):1326-1330 
8. Aquilanti L, Santarelli S, Silvestri G, Osimani A, Petruzzelli A, Clementi F: The microbial ecology of a typical Italian salami during its natural fermentation. Int J Food Microbiol 2007, 120(1-2):136-145.

9. Ganzle MG, Vermeulen N, Vogel RF: Carbohydrate, peptide and lipid metabolism of lactic acid bacteria in sourdough. Food Microbiol 2007, 24(2):128-138.

10. Aymerich T, Martin B, Garriga M, Hugas M: Microbial quality and direct PCR identification of lactic acid bacteria and nonpathogenic staphylococci from artisanal low-acid sausages. Appl Environ Microbiol 2003, 69(8):4583-4594.

11. Ahrne S, Nobaek S, Jeppsson B, Adlerberth I, Wold AE, Molin G: The normal Lactobacillus flora of healthy human rectal and oral mucosa. J Appl Microbiol 1998, 85(1):88-94.

12. Bringel F, Castioni A, Olukoya DK, Felis GE, Torriani S, Dellaglio F: Lactobacillus plantarum subsp. argentoratensis subsp. nov., isolated from vegetable matrices. Int I Syst Evol Microbiol 2005, 55(Pt 4):1629-1634.

13. Bringel $F$, Quenee $P$, Tailliez P: Polyphasic investigation of the diversity within Lactobacillus plantarum related strains revealed two L. plantarum subgroups. Syst Appl Microbiol 2001, 24(4):561-571.

14. De Bruyne K, Camu N, De Vuyst L, Vandamme P: Lactobacillus fabifermentans sp. nov. and Lactobacillus cacaonum sp. nov., isolated from Ghanaian cocoa fermentations. Int I Syst Evol Microbiol 2009, 59(Pt 1):7-12.

15. Siezen RJ, Tzeneva VA, Castioni A, Wels M, Phan HT, Rademaker JL, Starrenburg MJ, Kleerebezem M, Molenaar D, van Hylckama Vlieg JE: Phenotypic and genomic diversity of Lactobacillus plantarum strains isolated from various environmental niches. Environ Microbiol 2010, 12(3):758-773.

16. Torriani S, Clementi F, Vancanneyt M, Hoste B, Dellaglio F, Kersters K: Differentiation of Lactobacillus plantarum, L. pentosus and $L$. paraplantarum species by RAPD-PCR and AFLP. Syst Appl Microbiol 2001 24(4):554-560

17. Torriani S, Felis GE, Dellaglio F: Differentiation of Lactobacillus plantarum $L$. pentosus, and $L$. paraplantarum by recA gene sequence analysis and multiplex PCR assay with recA gene-derived primers. Appl Environ Microbiol 2001, 67(8):3450-3454

18. de Las Rivas B, Marcobal A, Munoz R: Development of a multilocus sequence typing method for analysis of Lactobacillus plantarum strains. Microbiology 2006, 152(Pt 1):85-93.

19. Breidt F, McFeeters RF, Díaz-Muñiz I: Fermented vegetables. In Food Microbiology: Fundamentals and Frontiers. 3 edition. Washington DC: ASM Press:Doyle MP, Beuchat LR 2007:783-793.

20. Luxananil $P$, Promchai $R$, Wanasen $S$, Kamdee $S$, Thepkasikul $P$, Plengvidhya V, Visessanguan W, Valyasevi R: Monitoring Lactobacillus plantarum BCC 9546 starter culture during fermentation of Nham, a traditional Thai pork sausage. Int J Food Microbiol 2009, 129(3):312-315.

21. Plengvidhya V, Breidt F Jr., Lu Z, Fleming HP: DNA fingerprinting of lactic acid bacteria in sauerkraut fermentations. Appl Environ Microbiol 2007, 73(23):7697-7702.

22. De Vuyst L, Vranckena G, Ravytsa F, Rimauxa T, Weckx S.S: Biodiversity, ecological determinants, and metabolic exploitation of sourdough microbiota. Food Microbiology 2009, 26(7):666-675.

23. Weckx S, Allemeersch J, Van der Meulen R, Vrancken G, Huys G, Vandamme $P$, Van Hummelen P, De Vuyst L: Development and validation of a species-independent functional gene microarray that targets lactic acid bacteria. Appl Environ Microbiol 2009, 75(20):6488-6495.

24. Weckx S, Allemeersch J, Van der Meulen R, Vrancken G, Huys G, Vandamme $P$, Van Hummelen $P$, De Vuyst L: Metatranscriptome analysis for insight into whole-ecosystem gene expression during spontaneous wheat and spelt sourdough fermentations. Appl Environ Microbiol 2011, 77(2):618-626

25. Weckx S, Van der Meulen R, Allemeersch J, Huys G, Vandamme P, Van Hummelen P, De Vuyst L: Community dynamics of bacteria in sourdough fermentations as revealed by their metatranscriptome. Appl Environ Microbiol 2010, 76(16):5402-5408.

26. Di Cagno R, De Angelis M, Limitone A, Minervini F, Simonetti MC, Buchin S, Gobbetti M: Cell-cell communication in sourdough lactic acid bacteria: a proteomic study in Lactobacillus sanfranciscensis CB1. Proteomics 2007, 7(14):2430-2446.

27. Connelly P: Lactobacillus plantarum - A literature review of therapeutic benfefits. Journal of the Australian Traditional Medicine Society 2008, 14(2):79-82.
28. Klarin B, Molin G, Jeppsson B, Larsson A: Use of the probiotic Lactobacillus plantarum 299 to reduce pathogenic bacteria in the oropharynx of intubated patients: a randomised controlled open pilot study. Crit Care 2008, 12(6):R136

29. Gareau MG, Sherman PM, Walker WA: Probiotics and the gut microbiota in intestinal health and disease. Nat Rev Gastroenterol Hepatol 2010, 7(9):503-514

30. Marco ML, de Vries MC, Wels M, Molenaar D, Mangell P, Ahrne S, de Vos WM, Vaughan EE, Kleerebezem M: Convergence in probiotic Lactobacillus gut-adaptive responses in humans and mice. ISME J 2010, 4(11):1481-1484

31. van Baarlen $\mathrm{P}$, Troost FJ, van Hemert $\mathrm{S}$, van der Meer $\mathrm{C}$, de Vos WM, de Groot PJ, Hooiveld GJ, Brummer RJ, Kleerebezem M: Differential NF-kappaB pathways induction by Lactobacillus plantarum in the duodenum of healthy humans correlating with immune tolerance. Proc Natl Acad Sci U S A 2009, 106(7):2371-2376.

32. Kleerebezem M, Boekhorst J, van Kranenburg R, Molenaar D, Kuipers OP, Leer R, Tarchini R, Peters SA, Sandbrink HM, Fiers MW, et al: Complete genome sequence of Lactobacillus plantarum WCFS1. Proc Natl Acad SCi U S A 2003, 100(4):1990-1995.

33. Siezen R, Boekhorst J, Muscariello L, Molenaar D, Renckens B, Kleerebezem M: Lactobacillus plantarum gene clusters encoding putative cell-surface protein complexes for carbohydrate utilization are conserved in specific gram-positive bacteria. BMC Genomics 2006, 7:126

34. Siezen RJ, van Enckevort FH, Kleerebezem M, Teusink B: Genome data mining of lactic acid bacteria: the impact of bioinformatics. Curr Opin Biotechnol 2004, 15(2):105-115.

35. Boekhorst J, Wels M, Kleerebezem M, Siezen RJ: The predicted secretome of Lactobacillus plantarum WCFS1 sheds light on interactions with its environment. Microbiology 2006, 152(Pt 11):3175-3183.

36. Francke C, Siezen RJ, Teusink B: Reconstructing the metabolic network of a bacterium from its genome. Trends Microbiol 2005, 13(11):550-558.

37. Teusink B, van Enckevort FH, Francke C, Wiersma A, Wegkamp A, Smid EJ, Siezen RJ: In silico reconstruction of the metabolic pathways of Lactobacillus plantarum: comparing predictions of nutrient requirements with those from growth experiments. Appl Environ Microbiol 2005, 71(11):7253-7262.

38. Teusink B, Wiersma A, Jacobs L, Notebaart RA, Smid EJ: Understanding the adaptive growth strategy of Lactobacillus plantarum by in silico optimisation. PLoS Comput Biol 2009, 5(6):e1000410.

39. Teusink B, Wiersma A, Molenaar D, Francke C, de Vos WM, Siezen RJ, Smid EJ: Analysis of growth of Lactobacillus plantarum WCFS1 on a complex medium using a genome-scale metabolic model. J Biol Chem 2006, 281(52):40041-40048.

40. Francke C, Kerkhoven R, Wels M, Siezen RJ: A generic approach to identify Transcription Factor-specific operator motifs; Inferences for Lacl-family mediated regulation in Lactobacillus plantarum WCFS1. BMC Genomics 2008, 9:145.

41. Wels M, Francke C, Kerkhoven R, Kleerebezem M, Siezen RJ: Predicting cisacting elements of Lactobacillus plantarum by comparative genomics with different taxonomic subgroups. Nucleic Acids Res 2006, 34(7):1947-1958.

42. Wels M, Overmars L, Francke C, Kleerebezem M, Siezen RJ: Reconstruction of the regulatory network of Lactobacillus plantarum WCFS1 on basis of correlated gene expression and conserved regulatory motifs. Microb Biotechnol 2010

43. Boekhorst J, Siezen RJ, Zwahlen MC, Vilanova D, Pridmore RD, Mercenier A, Kleerebezem M, de Vos WM, Brussow H, Desiere F: The complete genomes of Lactobacillus plantarum and Lactobacillus johnsonii reveal extensive differences in chromosome organization and gene content. Microbiology 2004, 150(Pt 11):3601-3611.

44. Kleerebezem M, Hols P, Bernard E, Rolain T, Zhou M, Siezen RJ, Bron PA: The extracellular biology of the lactobacilli. FEMS Microbiol Rev 2010, 34(2):199-230.

45. Zhou M, Theunissen D, Wels M, Siezen RJ: LAB-Secretome: a genome-scale comparative analysis of the predicted extracellular and surfaceassociated proteins of Lactic Acid Bacteria. BMC Genomics 2010, 11:651.

46. Kerkhoven R, van Enckevort FH, Boekhorst J, Molenaar D, Siezen RJ: Visualization for genomics: the Microbial Genome Viewer. Bioinformatics 2004, 20(11):1812-1814. 
47. Molenaar D, Bringel F, Schuren FH, de Vos WM, Siezen RJ, Kleerebezem M: Exploring Lactobacillus plantarum genome diversity by using microarrays. J Bacteriol 2005, 187(17):6119-6127.

48. Breiman L: Random Forests. Machine Learning 2001, 45(1):5-32.

49. Liaw A, Wiener M: Classification and regression by random Forest. $R$ News 2002, 2(3):18-22.

50. Zhang ZY, Liu C, Zhu YZ, Zhong Y, Zhu YQ, Zheng HJ, Zhao GP, Wang SY, Guo XK: Complete genome sequence of Lactobacillus plantarum JDM1. J Bacteriol 2009, 191(15):5020-5021.

51. Wang Y, Chen C, Ai L, Zhou F, Zhou Z, Wang L, Zhang H, Chen W, Guo B: Complete genome sequence of the probiotic Lactobacillus plantarum STIII. J Bacteriol 2011, 193(1):313-314.

52. Tomita S, Irisawa T, Tanaka N, Nukada T, Satoh E, Uchimura T, Okada S: Comparison of components and synthesis genes of cell wall teichoic acid among Lactobacillus plantarum strains. Biosci Biotechnol Biochem 2010, 74(5):928-933.

53. Nissen-Meyer J, Oppegard C, Rogne P, Haugen HS, Kristiansen PE: Structure and Mode-of-Action of the Two-Peptide (Class-Illb) Bacteriocins. Probiotics Antimicrob Proteins 2010, 2(1):52-60.

54. Nissen-Meyer J, Rogne P, Oppegard C, Haugen HS, Kristiansen PE: Structure-function relationships of the non-lanthionine-containing peptide (class II) bacteriocins produced by gram-positive bacteria. Curr Pharm Biotechnol 2009, 10(1):19-37.

55. Diep DB, Straume D, Kjos M, Torres C, Nes IF: An overview of the mosaic bacteriocin pln loci from Lactobacillus plantarum. Peptides 2009, 30(8):1562-1574.

56. Saenz Y, Rojo-Bezares B, Navarro L, Diez L, Somalo S, Zarazaga M, RuizLarrea F, Torres C: Genetic diversity of the pln locus among oenological Lactobacillus plantarum strains. Int J Food Microbiol 2009, 134(3):176-183.

57. Bourgoin F, Pluvinet A, Gintz B, Decaris B, Guedon G: Are horizontal transfers involved in the evolution of the Streptococcus thermophilus exopolysaccharide synthesis loci? Gene 1999, 233(1-2):151-161.

58. Broadbent JR, McMahon DJ, Welker DL, Oberg CJ, Moineau S: Biochemistry, genetics, and applications of exopolysaccharide production in Streptococcus thermophilus: a review. J Dairy Sci 2003, 86(2):407-423.

59. Rasmussen TB, Danielsen M, Valina O, Garrigues C, Johansen E, Pedersen MB: Streptococcus thermophilus core genome: comparative genome hybridization study of 47 strains. Appl Environ Microbiol 2008, 74(15):4703-4710.

60. Berger B, Pridmore RD, Barretto C, Delmas-Julien F, Schreiber K, Arigoni F, Brussow H: Similarity and differences in the Lactobacillus acidophilus group identified by polyphasic analysis and comparative genomics. J Bacteriol 2007, 189(4):1311-1321.

61. Raftis EJ, Salvetti E, Torriani S, Felis GE, O'Toole PW: Genomic diversity of Lactobacillus salivarius. Appl Environ Microbiol 2011, 77(3):954-965.

62. Siezen RJ, Bayjanov JR, Felis GE, van der Sijde MR, Starrenburg M, Molenaar D, Wels M, van Hijum SA, van Hylckama Vlieg JE: Genome-scale diversity and niche adaptation analysis of Lactococcus lactis by comparative genome hybridization using multi-strain arrays. Microb Biotechnol 2011.

63. Gross G, Snel J, Boekhorst J, Smits MA, Kleerebezem M: Biodiversity of mannose-specific adhesion in Lactobacillus plantarum revisited: strainspecific domain composition of the mannose-adhesin. Benefical Microbes 2010, 1(1):61-66.

64. Alper H, Stephanopoulos G: Engineering for biofuels: exploiting innate microbial capacity or importing biosynthetic potential? Nat Rev Microbiol 2009, 7(10):715-723.

65. Machielsen R, Siezen RJ, van Hijum SA, van Hylckama Vlieg JE: Molecular description and industrial potential of Tn6098 conjugative transfer conferring alpha-galactoside metabolism in Lactococcus lactis. Appl Environ Microbiol 2011, 77(2):555-563.

66. Carver T, Berriman M, Tivey A, Patel C, Bohme U, Barrell BG, Parkhill J, Rajandream MA: Artemis and ACT: viewing, annotating and comparing sequences stored in a relational database. Bioinformatics 2008, 24(23):2672-2676.

doi:10.1186/1475-2859-10-S1-S3

Cite this article as: Siezen and van Hylckama Vlieg: Genomic diversity and versatility of Lactobacillus plantarum, a natural metabolic engineer. Microbial Cell Factories 2011 10(Suppl 1):S3.

\section{Submit your next manuscript to BioMed Central and take full advantage of:}

- Convenient online submission

- Thorough peer review

- No space constraints or color figure charges

- Immediate publication on acceptance

- Inclusion in PubMed, CAS, Scopus and Google Scholar

- Research which is freely available for redistribution 